\title{
Domestic work in France and Italy: comparative case studies on the contemporary diffusion of informal employment
}

\author{
Elisabetta Pernigotti
}

Elisabetta Pernigotti is a postdoctoral researcher at the Gender, Work and Mobilities laboratory (GTM) of the Centre for Sociology and Policy Research of Paris (CRESPPA), at the National Center for Scientific Research (CNRS), France.

\begin{abstract}
The persistence of informal employment and its recent development in Western countries is often disregarded. This article argues that a gendered renewal of informal employment is taking place following global economic restructuring. Furthermore, it shows how informality might be recreated through the very policy initiatives that aimed at combating informality and structuring the highly feminised sector of care and domestic services. In spite of the differences in policy initiatives, qualitative analysis illustrates how the formalisation of these jobs remains partial, in France as in Italy, regardless of the absence or the presence of specific politics of regularisation. Industrial unemployment due to rural deindustrialisation is imposing on working-class women - formerly largely employed in factories - a new form of domesticity through a certain recognition of domestic and care work, between formality, 'grey work' and informality, which confines these same women to a universe that is family-based and precarious.
\end{abstract}

\section{Introduction}

Feminist critics of the global economy have shown how the precariousness of women's work and the prevalence of informal work result in unskilled women being positioned as advantageous 'sources' for businesses that relocate to the 'South' (Beneria, 2003; Elson, 2010; Elson \& Pearson, 1981). However, these critics focus only on the 'South' or on the migrant labour force.

This scholarly tendency to limit study on the effects of globalisation to the 'South' or its citizens strengthens the assumption of an epistemological difference between the 'North' and the 'South' (Spivak, 2009). In addition, it hinders the identification of common tendencies and dialectical modifications in the overall processes that characterise general transformations of professional activities (Glucksmann, 2005). One aspect of work reorganisation in the 'North' is the transition from industry to services, involving unqualified female employment. Whatpaths do international transformations of the economy follow in the de-industrialised 'North'? How does 
the precariousness of women's informal work expand and evolve in these countries? We consider informality ${ }^{1}$ (and formality) as an expression of complex social relations, in which gender and class are particularly relevant. Legally, informal employment is the absence of a regular labour contract. This perspective omits the societal formation and diffusion of informality (absence of a legal contract) and its complex relation to formality (the presence of a legal contract). We argue that the relationship between formal and informal employment is in fact an expression of broader social relations within society as a whole, and is thus pertinent to their transformation following global economic processes such as deindustrialisation of some regions in Western nations. We explore the dynamism within informality of employment as a process linked to formal employment. In order to explore current trends in how the division of labour is reorganised for less skilled workers in the 'North', this article examines tendencies of formalisation/informalisation in personal care services ${ }^{21}$ linked to the precarisation of working-class women in France and in Italy. This sector has an impact on gender relations at many levels (Le Feuvre \& Martin, 2001). The question of formalisation relates to processes of valorisation and devalorisation of work that is culturally defined as feminine, and is at the centre of the family division of labour. Recognition of domestic work is at the core of any reflection on the social and sexual division of labour in an equitable society (Letablier, 1996). From this perspective, contractual formalisation of these jobs may constitute a step towards the recognition of domestic work as such, through the mediation of the market. But, paradoxically, the informalisation of contractual relations in this sector still continues, now, as in the past, both in France and in Italy, in spite of national differences in public policy. In France, this sector of activity has been the object of an explicit impulse towards regularisation, whereas initiatives taken by the Italian public authorities against informal work do not take into account this sector of activity, the predominant informality of which is not considered a question for public regulation.

What are the differences between France and Italy in this same sector and concerning the importance of informal work? How can initiatives towards formalisation change the contractual position of female workers? How can a job's status (its level of informality) influence attitudes towards work and female employment, and possibilities for professional choice? The attention of public policy to this sector represents a symbolic step towards recognising the value of care-giving work. In France, the commodification of such jobs is the result of numerous initiatives aiming to facilitate the externalisation of domestic work. New forms of rationalisation for this work are appearing because of such transformations (Pernigotti, 2010). The influence of recent free-market ideology on public policy in the 'North' appears to orient the market towards greater competition.

\footnotetext{
1 According to the definition of informality adopted by the International Labour Organisation, an employee is considered informal when 'the relation to the work is not submitted to standard work regimentation, taxation, social protection and coverage of benefits linked to the job' (International Labour Conference, 2002). Informal work thus does not necessarily concern workers considered 'illegal' for reasons linked to their residential status.

$2 \quad$ For the purposes of this article, we define personal care services as including unqualified domestic cleaning, care for the elderly, care for the sick and childcare (baby sitting).
} 
The mainstream tendency to correlate informality with developing countries, or to consider it as a remnant of outdated forms of employment, participates in the depoliticising of socio-economic problems, adding epistemological violence to economic violence (Spivak, 2009). The aim of this study is to analyse its contemporary manifestations in the 'North'.

\section{The institutional context}

In France, public policies of formalisation for the care sector began in the 1980s, with the introduction of 'service-employment cheques', 'service-employment tickets' and 'universal employment tickets'.

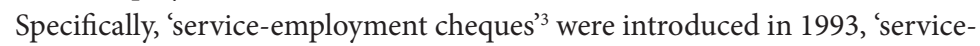
employment vouchers's in 1996 and 'universal employment cheques' ${ }^{\text {'5 }}$ in January 2006. They represent an institutional development of new contractual relations to simplify hiring procedures. To facilitate formalisation, a complete exoneration of charges, limited to selected services, was applied to wages paid to domestic employees hired by specific social categories - the handicapped and people over 70 years old. Since 1991, family care has qualified for tax reductions in France. In addition, in February 2005, a development plan for personal care was adopted: the so-called 'Plan Borloo' which granted all employers a 50\% reduction in social insurance charges.

These measures were intended to reverse general trends towards the devaluation of unskilled domestic jobs (Sarti, 2000; Battagliola, 2004). However, they deliberately encouraged the expansion of such jobs, notably by demand-side measures, such as tax deductions (Letablier, 1996). In addition, work in this sector was reorganised through the intervention of the state: it is now regulated by different types of organisations and, more recently, by businesses. Strong competition between many types of formal contracts and organisations presents an inherent risk of short-term competition based on a reduction of labour costs, and a drive for gains in productivity. This expanding institutionalisation, which expresses itself through the formalisation of a branch of what is generally known as 'informal work', may be considered an attempt to improve the status of these jobs (Dussuet, 2008).

3 Chèque Emploi Service (CES). In 1993, the CES scheme was introduced for individuals employing someone for eight hours or fewer a week in their household. The scheme aimed to simplify the process of hiring, paying and making social security contributions for a domestic worker by paying their salary using a system of cheques, which could be purchased at a local bank. The employer could claim an income tax reduction of $50 \%$ of the sum spent on purchasing the cheques. Meanwhile, the employee would also benefit, because the salary paid could not be less than the national minimum wage, plus a 10\% indemnity for paid leave.( http://www.eurofound. europa.eu/areas/labourmarket/tackling/cases/fr003.htm).

$4 \quad$ Titre Emploi Service (TES) In 1996, a similar scheme to the CES was created, namely the TES. Unlike the TES scheme, under the CES the domestic worker had to be employed through a private agency or association. Workers received a TES voucher, similar to a luncheon voucher, from their employer as part of their salary, from regional or local authorities or from associations in order to pay for domestic services. As households were limited to purchasing domestic services from organisations rather than individuals, this system offered better guarantees both to workers (who would receive support from an organisation) and employers (who were guaranteed a better quality service as the organisations providing services are subject to government approval) (http://www.eurofound.europa.eu/areas/labourmarket/tackling/cases/fr003.htm).

$5 \quad$ Cheqque Emploi Service Universel, (CESU). Under the CESU, two types of cheques are available: CESU Banquaire, are issued by banks to be used by individuals for directly paying a worker; CESU préfinancé, similar to TES vouchers, are used when the service is funded by a third party (http://www.eurofound.europa.eu/ areas/labourmarket/tackling/cases/fr003.htm). 
In Italy, on the other hand, the care and domestic work sector remains fairly unstructured and informal. Employment using formal contracts (whether temporary or permanent) are rare. Although co-operative societies exist that provide social services and receive funding through local authorities, no initiative nearly as large as the French example has been taken to reduce the proportion of undeclared work in this sector. The only initiatives to encourage formalisation of informal work taken since 2003 have been limited to industrial employment and the employment of migrants, notably through regularisation of foreign workets by means of contracts called 'badanti' (care for the elderly). We can thus conclude that there is an absence of political will to normalise the domestic employment sector in Italy.

This paper addresses the questions: what are the differences between France and Italy in this same sector, concerning the importance of informal work? And how can initiatives for formalisation change the contractual position of women workers?

\section{Methodology}

The scope of this study does not include a full portrayal of these two national examples, but seeks to uncover the main features of the lived experience of informal domestic employment in an era of service-sector expansion.

In examining the evolution of care-giving jobs for women in France and Italy, I chose to examine two rural areas in the process of deindustrialisation: Calvados (in Lower Normandy, France) and Eporediese (in Piedmont, Italy), which have traditionally been home to populations affected by economic fluctuation. The chosen populations do not have particular issues regarding their residence status or nationality, which could lead to a deterioration in work for other reasons than those explored, which were gender and class. This methodological choice made it possible to situate professional identity and the relation to formality/informality uniquely at the level of employment status. Calvados and Eporediese are both influenced by the process of ageing of their populations. In both regions too agriculture is in decline, with tourism taking over as an alternative source of revenue. The chosen territories are characterised by economic decline, which makes them rather unattractive for immigration. This made it possible to focus precisely on the informality of domestic and care work, separated from other current phenomena touching this sector, such as migration and discrimination towards people of foreign origin or descent in the labour market.

The following analysis is based on 30 biographical, semi-directive interviews each lasting approximately two hours, conducted between October 2004 and June 2005 with rural women between the ages of 35 and 65, of French or Italian nationality, in precarious work situations. I chose the interviewees with the help of a guide for each area: in each case, a 45-50-year-old women who had always lived in the area and worked in the social care sector and had thereby gained a deep knowledge of the local inhabitants.

The interviewees were identified based on two criteria: they all worked formally and/or informally for wages that were below the full-time minimum wage and they were all actively seeking work in the community where they lived (or in surrounding villages). 


\section{The influence of local economic contexts on professional choice}

Two factors determine entry into the job market: the economic context of proximity and the economic needs of the family. For the rural proletariat in the 1960s and 70s, the possibility of formal work in a factory or small business presented itself as the best option for girls. Parents did not contest their choice to leave school as soon as legally possible. They entered the workforce around the legal school-leaving age (16 years old). The jobs available in the area structured the life of the women and teenage girls who lived there (Massey, 1997). In the tradition of employing female teenagers in the unqualified industrial sector, the positive economic prospects of the industrial sector and their youth facilitated access to industrial employment.

Starting a job was rarely identified as an individual choice and was often described by the interviewees using the passive voice. 'They put me in the factory' was how Léa expressed it, the deciding agent behind 'they' being her parents. Many interviewees went automatically from school to factory, as was the case for Marie who went to work at 16 to her first factory job where she stayed until she was laid off for economic reasons.

It was my initiative, I didn't like school very much. My parents didn't say much at that time, this was our path, we stopped school and went straight to work. (Marie). These women's transition from school to factory depended on three criteria: the possibility of formal work, logistic proximity and reduced time searching. The entry into manual work did not present any problems for their families: it was considered normal for young women to start work at that age, and factory work was even considered the ideal employment for young women with a working-class background.

For some, family connections further facilitated access to a first job. Julie, when asked about her studies, talked to us about her entry into a local road transportation company, where her father and grandfather were mechanics.

I only had a technical diploma as a typist. And then, as I became part of the company ... I always worked in the company ...over 30 years. (Julie)

The choice was so simple that it didn't require any individual thought on her part; the company was simply described as 'the business', indicating a personal appropriation of the traditional workplace of her family. In this case, a professional family identity had been accumulated over several generations through the proximity of places of work and residence. Twenty-nine years later, the company shut down.

All the interviewees had experienced having to leave manual jobs (in sectors including textile and clothing, food and small utensils) when their employers closed down or relocated. After periods of unemployment, they could only find unstable jobs in domestic services and personal care.

However, French and Italian policies in the sector differ. France is at the forefront in Europe for the regularisation of this sector, which has resulted in competition between independent workers, organisations and private companies. Here, Government measures have explicitly aimed to eliminate informal work. In Italy, on the other hand, the domestic services and personal care sector is dominated by informal employment, without any Government policy for reducing undeclared work. 
A comparison of the two contexts raises the questions: does public action in France enforce relations of domination created by the market, or is it advantageous to women workers? And how does the structure of the personal service sector influence the prevalence of informal work? These questions are addressed in the next section, firstly by showing the variance in practices of informal work and secondly by exploring perceptions of informality.

\section{The articulation of formal and informal employment}

Contractual arrangements and job standards involving informal employment differ significantly between the two countries.

Comparing the two contexts, we first observe differences in legislation governing contractual practices in the domestic and care work sector, notably regarding conditions of employment. Practices linked to contractual and legal systems of formalisation reveal mechanisms specific to each country which contribute to the (re)production of a common norm: job insecurity of working-class women through devaluation of their work.

In the Piedmont region of Italy, analysis of socio-professional paths of the women workers who werw interviewed showed that only periods of full-time manual labour were regularly declared. Among cleaning and personal care activities, the only activities that were sometimes partially declared were those involving cleaning businesses or restaurant maintenance. On the other hand, cleaning services and care provided for the elderly in private homes were never declared.

In the Lower Normandy region of France, by contrast, differentiation between formal and informal work according to job conditions (notably between work for businesses and work in individuals' homes) is less clear because of the force of the legal initiatives targetted towards flexibility and organisation in the care and domestic work sector. These have significantly reduced the proportion of informal work in the sector, without totally eliminating it. In addition to what interviewees labelled 'black' work, a synonym for informal work, a new category of hybrid job has appeared, that of work which could be named 'grey' which represents hours of both formal and informal work. Following the introduction of incentive measures for formalisation, the transformation of 'black' work into 'grey' work has intensified: in France, many female workers accumulate both declared and undeclared jobs for the same employer. The intervention of job intermediaries (organisations) makes it easy for employers to change their requirements and responds to their needs in terms of flexibility of demand - whether this is to cater to temporary or permanent needs for care.

In France, contracts specific to the care and domestic service sectors have recently been developed, with the effect of partially replacing informal employment, but also partially sustaining its development.

The French service-employment cheque - created for domestic and care service employment - was originally related to a type of contract that could be considered highly flexible. It enables an individual to hire a worker by the hour by simplifying administrative tasks while allowing access to social insurance, and thus to unemployment compensation and contributions towards retirement pensions. In 
reality, the social advantages that it procures for workers are minimal, because its use does not necessitate a maximum duration of work (although one hour of work is sufficient to activate coverage in case of an accident on the job, which can also be activated a posteriori; the entitlement that it gives to allocations for unemployment compensation or old age pension are minimal, because they are proportional to the duration of the work).

The research illustrates the extent to which service-employment cheques contribute to the institutionalisation of unstable employment in France, contrary to the stated objectives of this initiative. Thus, Sophie A., questioned about the use of this measure, described the distortion in its practice, leading to encouragement and facilitation of unstable job offers, even if they are formalised. She works 'on the grey', combining formal and informal work in care for the elderly and home cleaning. The employer's enthusiasm for this type of contract, according to Sophie A.s experience, stems from the way it allows for variations in the requirement for these services. It leaves the employer free from any regular commitment to employment. Indeed, in Sophie A's opinion, it provides casual replacement for a regular informal female worker. In this sense, the service-employment cheque depersonalises the work relationship, which makes it all the more flexible.

... because that's the advantage of the service-employment cheque, you have the employment cheque and it's perfect, you don't need to hire anyone! It allows you to take someone on momentarily. (Sophie A.)

The variety of hiring possibilities, such as the service-employment cheque, or buying in services from specialised organisations, leads to competition between female workers, weakening their power to negotiate. The extreme ease of flexible formal hiring diminishes the power of contractual negotiation of female workers and forces them to compete with each other. Charlotte B. describes the vulnerability to which a legal form such as the service-employment cheque exposes female workers, such as insecurity and fluctuations in pay, especially regarding child-care. This is even more important because competition is high.

Charlotte B. is 45 years old, and works as a certified maternal assistant. She also takes care of tasks such as ironing for the same employers, but paid informally. She has been working in this way for six years, after two years of unemployment following a period of 16 years working as a full-time manual worker which came to an end when she was laid off because of the firm's economic problems. Her current income is less than when she worked full-time in the factory. In addition, her work as a certified maternal assistant undergoes fluctuations during periods of school vacation. She receives her salary through service-employment cheques. This, she says, makes her fearful of competition and of being replaced. Consequently she does not dare to requesting that her employers fully respect her rights.

In euros, we can say [that I earn] 400 euros [per month]. But when Christmas vacation comes, paid by the hour, I need to check, because there is something missing, when Christmas or school vacations come, it's true that they [the parents of the children I care for] don't pay us. Even if it's stated that they have to pay us half a day, they don't pay us. You know, if we ask them, they will say they'll 
get someone else, and there you go! Plenty of competition ... they can say that the children don't need you anymore. (Charlotte B.)

In France, a variety of formal and informal modes of hiring co-exist, institutionalising the instability of jobs in home-based care and domestic cleaning. The ease with which jobs can be managed by organisations or through the personal contacts of workers, as well as the wide range of different hiring possibilities (indirectly, through the intermediary of an organisation, or directly, by the individual employer, by use of employment-service cheques and/or informally) seems to diminish the margin of negotiation of female workers and further exposes them to conditions of unstable work. These results contradict the stated virtues of this measure, which was intended to promote formalisation. Furthermore, the practice of combining informal work with the establishment of a contract for formal work is widespread, a practice which is indeed recognised by institutional leaders, such as managers of intermediary employment agencies.

Compared with the precariousness of the formal contracts in the care and domestic sectors, informal employment may, in fact, present relative advantages in this context. Paradoxically, in both France and Italy, informal work sometimes seems to be more advantageous for workers as an alternative to formal unstable work. In both countries, an important characteristic of informal work in the sector is its relative stability, sometimes in opposition to the instability of formal part-time jobs and the temporary contracts that some of our interviewees had. Here, the most notable examples were assisted part-time contracts for the Municipality - in daycare, cafeteria and maintenance work. These contracts were granted for one year, with the possibly of being renewed twice.

For ten years, I always had the same people [for informal work] and then I worked with a two-year assisted contract ... OK it was good, but at the end of it I found myself without a job. (Sophie A.)

In both countries, informal working relationships with individuals are most often of long duration; in addition, the multiplicity of employers protects against variations in demand. In Italy, many studies have shown that there an informal worker may often continue working for the same individual employer for ten years, or even longer. These practices are all the more advantageous in that they allow a certain stability, in contrast with formal - but flexible - measures, which create job instability. The growth of intermediaries in the cleaning sector constitutes another example of this. Thus, the Italian Valeria A., working 'on the grey' occupies a formal job as a temporary worker in a cleaning co-operative, which she combines with domestic and care services jobs in individual homes.

Cooperatives [of cleaning services] offer temporary work, like that, fiust for a fortnight. And you continue that way all year. You get all the benefits [access to social protection] in working that way. And that way they don't have to employ anyone!( Valeria A.)

She recounted her disappointment with partially-declared work in a firm which suddenly stopped employing her.

In one [firm], I was able to do ten hours a day, officially three hours. I felt exploited because when I needed them, they eliminated me. (Valeria A.) 
The Italian Rosa C. was a full-time manual employee in a lamp-making factory on the brink of bankruptcy Although this was a totally legal job, this employer didn't pay regularly. She contrasted this situation with the individuals she worked for (informal domestic employers), who never failed to pay her for the cleaning hours as informally agreed which she greatly appreciated. In Italy, as in France, penalties for informality in the employment relationship are solely the responsibility of the employer, which is favourable to the stability of contractual long-term relations and respect for the agreed terms. This is accentuated by the absence of intermediary organisations for household services in the Italian context, making it much more difficult to find a worker for domestic cleaning or home-based care there than in France. The overall situation in Italy reinforces the power of negotiation of informal domestic workers.

\section{Stigmatisation of informality and social control in informal work}

Stigmatisation of informality and its association with 'illegal work' touching female workers is one of the negative repercussions of these initiatives for flexibility and regularisation of the sector. In France, this is manifested by the hesitation of interviewees to reveal their informal activities, notably when these are combined with being in receipt of welfare benefits. Thus Louise C. tells us about taking care of a handicapped, ill woman until her death. She stayed with her for four years for 350 euros per month. She adds to her statement '...I don't usually mention it ... you know, it was undeclared' (Louise C.).

French workers experience a high level of social control and informing. Some women expressed fear of rumours and the danger that they represent for welfare benefits. Pascale D., for example, is mistrustful of neighbours with whom she has had problems in the past regarding maintenance of her unemployment compensation. 'You know, here where we live ... there are jealous people. So if you work for someone and they know that you are unemployed, they are quick to turn you in ... (Pascale D.)

In contrast to Italy, where informal work is 'discussed' without fear, in France it seems to be more hidden, because of a gradual transition towards the imposition of a new social norm codifying market relations in this sector of activity. According to the French interviewees, times have changed, with the introduction of various measures of formalisation for informal work. Social recognition of the completely informal job has diminished, all the more so because this type of job must remain a secret from the social environment. Hiding it reinforces the general invisibility attached to domestic labour and its lack of recognition. Our study reveals a lack of recognition for the employment activities of these workers within their own families, expressed in continual requests for help or services on the part of the spouse, who refuses to respect their partners' employment schedule. In this sense, in France, attempts at formalisation appear, paradoxically, to have diminished the recognition of these informal activities, which the women themselves often reduce to the pleasure of being useful, rather than considering them as constituting a job. Louise, 55 years old, expressed it in these terms: 'I wanted to be useful. If I can do something, anything, everything they ask me to, anything, I'm ready'. She was referring here to the versatility of her activities for the 
elderly people who employ her, whether this involved cleaning their teeth, washing their hair, housekeeping or driving them somewhere.

The relation to regularisation differs between the two countries and according to the type of employer. Among the Italian interviewees without formal work contracts, few asked, or imagined asking their employers to formalise their work contracts. From the Italian workers' point of view, the degree of viability of such a plan depends on several criteria including the type of employer, the number of hours worked and seniority.

In Italy, formalisation of a work contract is only seen as viable for employees of cleaning companies or of businesses, but not in the sector of personal domestic care service. Workers never ask individual employers to establish an employment contract. In addition, the request for regularisation is only formulated after a certain time, like a trial period, which legitimises the request in their eyes. Maria B., a cleaner in a restaurant, said that the formalisation of her contract was expected as a form of recognition for her work. It may represent an employer's respect for an engagement at the moment of recruitment, as described by Valeria A., working for a cleaning business: 'At the moment, I am working for a business that promised me four hours declared ... so I am happy'.

In contrast to their French counterparts, informal Italian workers did not display fear of the consequences. For these Italian women, concern for their retirement was the main reason for requesting the establishment of a formal work contract.

The problem is retirement ... I would like to ask the restaurant if they can regularise these hours. I'm going to try telling them ... I've been working here for nine months. To be legal [formal employment] is another matter, it's different, you have your 'marchette' [stamps for retirement contributions] and everything. Later, you find yourself with a retirement pension. (Maria B.)

Although they are aware of the importance of the social benefits attached to formal work, women who provide care and domestic services in Italy do not feel that requests for formalisation are legitimate, mainly because of the limited number of hours they work for each family of employers. Not only are the hours worked for any given employer typically short (for example, two hours a fortnight, for house-cleaning), but these can also change over time (for instance, rising to eight hours of work a week, or even more, if a sick person needs to be cared for). Nevertheless, in Italy there is no legal lower limit for establishing a formal working contract, even when the work in question involves a minimal number of hours of work. On the other hand, even though it is normal for women in Italy providing service to families to have been doing so for a considerable length of time (sometimes exceeding a decade), they do not express the need for a contract because informal work represents the social norm. Rosa illustrates this situation, where there is a (legal) interest in regulation, but considerable social courage is required to digress from the dominant practice in this sector:

I can't ask to be regularised, I would like to, but I work for different people, I have a dozen employers, it would be too much to dare ask for a regularised contract, like that, for two hours. (Rosa)

In France, the women's relationship to the formalisation of a work contract is different: access to social coverage is primarily perceived by those concerned as an insurance 
against work accidents, especially by those who have previous experience of formal employment. This was the case for Louise C. At 55 years, and after eleven years of fulltime manual labour that ended in redundancy, she pursued various jobs in care and domestic services, sometimes in partially declared, 'grey' work (as a certified nanny for a handicapped girl, giving assistance to the elderly, cleaning etc.). The serviceemployment cheque allowed her to receive some minimal social benefits, such as coverage in case of accidents, which is effective even in the case of partial declaration. I don't only work for the organisation, I also go to peoples' homes, I am declared a little bit, you know ... I go ... I do the housework, so, sometimes, I do ten hours and then I am declared for two hours, you know that's the way it is, for [accident] coverage. (Louise C.)

In France, informal work also carries a financial penalty. French workers working informally normally earn only about half the hourly pay that they receive for formal work and this discrepancy remains even when they are working for the same employer in both capacities, (when the employer only partially declares the work - with an inferior number of hours). For the worker, this economic loss is in addition to the loss of social benefits (particularly the loss of unemployment cheques in the present, and access to retirement in the future). For the employers this practice can only be beneficial.

In Italy, pay for informal work does not differ significantly from the minimum wage established by public policy, with reference to which it is more or less calculated. On the other hand, some of the earning of undeclared workers can follow a kind of 'gift logic', typical of rural areas. Thus one Italian worker considered that some of her hours of work (night care for a sick person) were 'voluntary', since she did not take money for them, doing the work in order to cultivate her relationship with her employers and ensure that it lasts.

In either case, when they do informal work, these workers do not receive the monetary equivalent of the social benefits that have not been paid for them. The pay of French women seems on the whole to be less, but they benefit from a partial regularisation of their working hours which leads to certain minimal social benefits (coverage in case of accident on the job, and a small contribution to retirement, unemployment compensation, etc.). Even if the establishment of a formal work contract can mean undeniable advantages for workers in both countries, a more general evaluation of the working conditions and the views of the interviewed population indicates a more nuanced appreciation. In addition to the financial question and that of access to social benefits, maintenance of the long-term relationship with the employer is one of the central aspects that must be accounted for to understand the strategies of Italian workers. In spite of differences in terms of legal measures and their use, an asymmetrical relation of power between workers and their employers means that the workers do not seem, in either of the two countries, to be able to have their interests fully respected.

\section{Conclusion}

This research shows the centrality of gender and of qualifications in the local and specific configuration of precarisation, which in the deindustrialised 'North' involves the development of a personal care service sector and the diffusion of informal work. 
Through the variety and breadth of informal activities in Italy, as well as the total absence of a plan for formalisation of personal care services in individual homes, we can conclude that informality is more prevalent and widespread there than in France. In addition, we can observe in Italy a more significant continuity in informality between different sectors of activity and a possibility for workers to combine several activities, job statuses and sectors (individuals, companies, restaurants, small businesses), thus working for multiple employers. In this way, the Italian women who were interviewed would experience less professional segregation than their French counterparts. In France, by contrast, the women interviewed tended to work exclusively for the domestic and care service sector. In addition, the range of tasks carried out indicates that there has been less professionalisation of the activities of care and cleaning in Italy, where there is also a tendency to undertake any other activity considered as unskilled.

In spite of these differences, the formalisation of these jobs has always remained partial, in France as in Italy, both in the absence and in the presence of specific politics of regularisation. It seems that in France, the attempt to combat informal work has provoked a situation where attempts at formalisation lead paradoxically to a situation similar to that in Italy, where workers are trapped in an underpaid job market, benefiting from little social recognition and where formalisation constitutes an exception. In France, these attempts appear to have institutionalised the instability of working conditions and generated further discrimination against workers who are informally employed. The problems faced by poor women workers are linked to the contemporary reconstruction of informality in the 'North'. Informality may also be part of the strategies of resistance of unemployed female manual workers. The policy initiatives to fight it are actually acting against such strategies. They symbolically affirm the supremacy of legally-recognised work, following the 'principle of visibility' (Foucault, 1994:11), but such policy measures do not facilitate access to stable jobs.

The process of construction and organisation of this sector of the market - enhancing the commercialisation of these activities - reproduces the main characteristics of its object (care and domestic work), mirroring the more general properties of female work, which remains confined in its undervalued social position. Thus the positive aspects of attempts at formalisation in France are limited by their partial application and by their extremely flexible character. Changes brought about through the formalisation initiatives in France are partially disadvantageous to workers because of the stigmatisation of informality; they must hide their informal jobs. In this way, a 'double discrimination' has emerged, due both to the status of the stigmatised job and to the under-recognition of domestic work.

In France, governmental initiatives for formalisation have not eliminated informality and have contributed considerably to the heightening of competition, due to contractual flexibility, mostly to the advantage of individual employers. Whilst the hours worked are divided between several employers and forms of employment, the workers continue to have very limited earnings and social benefits (Dussuet, 2002). The model of formalisation undertaken in France seems to reveal the possibility that a trap can develop through the manipulation of contemporary social needs, supported by the solvency of demand, imposing a new form of domesticity on working-class women, 
through a certain recognition of domestic work, between formality, 'grey' work and informality, which confines these same women in a universe that is family-based and precarious (Walby, 1997; 1998).

(c) Elisabetta Pernigotti, 2012

\section{REFERENCES}

Battagliola, M. (2004) Histoire des femmes, Paris: La Découverte.

Beneria, L. (2003) Gender, Development and Globalization: Economics as if All People Mattered, London: Routledge.

Dussuet A. (2002, 2008) A, Dussuet (2008) 'Genre et mobilisation de la subjectivité dans le travail. L'exemple des services à domicile aux personnes âgées', D. Linhart D. (ed.), Pourquoi travaillonsnous?, Toulouse: Editions ERES.

Dussuet A., (2002) 'Le genre de l'emploi de proximité', Lien Social et Politiques, 47:143-154.

Elson, D. (2010) 'Commerce international, égalité des sexes et avantage compétitif', in J. Falquet,

H. Hirata, D. Kergoat, B. Labari, N. Le Feuvre \& F. Sow, F. (eds.) Le sexe de la mondialisation, Paris: Presses de Sciences Po.

Elson, D., Pearson R. (1981) 'Nimble fingers make cheap workers', Feminist Review, n.7: 87-107 Foucault M. (1994) Dits et écrits, vol.1, Paris: Gallimard.

Glucksmann M. (2005) 'Shifting boundaries: the "total social organisation of labour revisited", in J. Parry, R. Taylor, L. Pettinger \& M. Glucksmann (eds) The New Sociology of Work, Oxford: Blackwell-Sociological Review.

International Labour Organisation (2002) 'Decent Work and the Informal Economy', Session 90, International Labour Organisation: Geneva: 7.

Le Feuvre N., \& J. Martin (2001) 'Les emplois de proximité aux ménages: de la solidarité à la précarité des emplois féminins', Némésis, 3:299

Letablier A.-M. (1996) 'Lactivité professionnelle des femmes en France sur fond de pénurie d'emplois', Lien social et Politiques, 36: 93-102.

Massey D. (1997) 'Industrial Restructuring as Class Restructuring: Production Decentralization and Local Uniqueness', in L. McDowell \& J. Sharp (eds.) Space, Gender, Knowledge, London: Arnold.

McDowell, L. (2001) 'Father and Ford revisited: gender, class and employment change in the new millennium', Transactions of the Institute of British Geographers, 26:448-464.

Pernigotti E. (2010) 'Laction publique pour le développement de l'emploi dans les services à la personne. Des réformes à l'avantage de qui ?', Documents de travail du Mage,15:71-80.

Sarti, R. (2000) Work and Toil. The Breadwinner Ideology and Women's Work in $19^{\text {th }}$ and $20^{\text {th }}$ Century Italy, Bologna: S.I.P.

Spivak, G. (2009) Les subalternes peuvent-elles parler? Paris: Éditions Amsterdam.

Walby, S. (1997) Gender Transformations, London: Routledge.

Walby, S. (1998) 'Les figures emblématiques de l’emploi flexible', M. Maruani (ed.) Les nouvelles frontières de l'inégalités, Paris: La Découverte. 